\title{
"Are My Songs Literature?"1: A Postmodern Appraisal of Bob Dylan's American Popular Music Culture
}

\author{
Marwa Essam Eldin Fahmi \\ MISR University for Science \& Technology, Egypt \\ E-mail: marwa.fahmy@must.edu.eg
}

\begin{abstract}
The current study is a postmodern appraisal of Bob Dylan's artistic career and vocal gestures to examine the way melody in popular music works in relation to speech and singing, the grand and the ordinary. It historicizes Bob Dylan's protest music of the 1960s within the paradigm of folk music culture. Dylan's music is full of riffs, blues sequences, and pentatonic melodies - all heavily part and parcel of blues, folk, gospel, and country music. It is the music that dwells on the pleasures of repetition, of circularity, and of the recurring familiar tune integrated within Dylanesque poetics of rhyme delivered with his idiosyncratic, deep and intense range of voices. Dylan is the official son of the legacies of social, communal, and ritual music-making that mirrors contemporary pop and rock back to folk and blues, street-sung broadsides and work songs, the melodies of medieval troubadours, and the blessed rhythms of Christianity and Judaism. The study is an attempt to illustrate how musicology and ethnomusicology in particular can contribute to understanding Dylan as a 'performing artist' within the postmodern paradigm. Thus, the study seeks to establish Dylan as a phenomenal, prolific postmodernist artist, as well as an anarchist. The power and originality of Dylan's music constitute a prima facie case that his performances should be considered postmodernist art.
\end{abstract}

Keywords: Performing arts; American popular music; Dylanesque; Protest music; Postmodern culture

\section{INTRODUCTION}

\section{On Popular Music Culture: A Postmodern Reading}

"Good music is the authentic expression of something - a person, an idea, a feeling, a shared experience, a Zeitgeist" — Frith (1987, p. 136).

Fine arts have been understood since the eighteenth century to include music along with painting, dance, and poetry. This notion of serious music appeared to be determined by masterpieces of Western classical music during the nineteenth and early twentieth centuries, in contrast to street singing or popular music. In Keywords: A Vocabulary of Culture and Society (1983), Raymond Williams argues that "popular" originally referred to something of the people or the ability to "appeal" to all people, and thus was "common", "low", or "base" (Williams, 1983 , p. 236). Williams suggests that "popular" bears three related senses: (i) inferior work, (ii) work that deliberately sets out to win favor, and (iii) work that is well liked by many people (Williams, 1983, p. 237). Folk ideology rejects the mass culture of television, Hollywood movies, and electric pop music. The folk crowd romanticizes the oppressed and the bohemian's opposition to a capitalist and affluent society has been investigated and examined. Popular music is the music of the masses that may sound revolutionary and it has galvanized many movements and causes. 
It is also a way to champion economically, socially, and politically marginalized citizens. In other words, American folk songs — as the study unveils — reflect theories of cultural pluralism and cosmopolitanism because they incorporate ethnic songs from communities of recent immigrants. Folk music can be seen as a living culture and it is inherently democratic since it is 'communally' composed and 'communally' accepted.

With this rationale, popular culture is the authentic culture of 'the people' and as a definition of popular culture; it is "often equated with a highly romanticized concept of working-class culture constructed as the major source of symbolic protest within contemporary capitalism" (Bennett, 1980, p. 27). This sheds light on the theories of popular culture as theories about the constitution of 'the people'; popular culture is a contested site for political constructions of 'the people' and their relation to 'the power bloc':

'the people' refers neither to everyone nor to a single group within society but to a variety of social groups which, although differing from one another in other respects (their class position or the particular struggles in which they are most immediately engaged), are distinguished from the economically, politically and culturally powerful groups within society and are hence potentially capable of being united - of being organised into 'the people versus the power bloc' - if their separate struggles are connected (Bennett, 1986, p. 20).

Popular culture is a deeply political concept: "Popular culture is a site where the construction of everyday life may be examined. The point of doing this is an attempt to understand a process or practice that is also political, to examine the power relations that constitute this form of everyday life and thus reveal the configuration of interests its construction serves" (italics mine, Turner, 1996, p. 6).

This underscores the debatable relationship between postmodernism and popular culture. The main point to centralize is the claim that postmodern culture is a culture that no longer recognizes the distinction between high and popular culture. This is a reason to celebrate an end to an elitism constructed on distinctions of culture and the configuration of the supposed interpenetration of commerce and culture. In other words, the postmodern blurs the distinction between 'authentic' and 'commercial' culture as manifested in the association between commercials and pop music. For example, there is a growing list of artists who have had hit records as a result of their songs appearing in commercials. One of the questions this association raises is: "What is being sold: the song or product?" I suppose the noticeable answer is both. It is now possible to buy CDs of hit songs that have become successful as a result of being deployed in advertisements.

Lawrence Grossberg-American cultural theorist - foregrounds the question of genuineness and truth by identifying three forms of authenticity within rock discourses: the first revolves around the romantic ideology of rock music as a magic construction expressive of dense community, the second form refers to dance-oriented and black genres localized in the construction of a rhythmical and sexual body, and the third form is postmodernist as it plays with styles in a cynical mood that reflects a realistic sincerity (Grossberg, 1993, p. 185). Dylan's intensity of voices evokes both personal experience and depth of meaning within the paradigm of political ideologies. This underlies a high sense of authenticity, yet that Dylan's music is deployed for a culture industry to be marketed as a commodity brings the aura of authenticity into question. Music has brought postmodernism to the public through both live performances and recordings to fashion public identities and to approach the needs of the listeners as a serious art, not as sheer entertainment, diversion, or relaxation.

Musicology's engagement with postmodernism embraces minimalism, nostalgic moods, pastiche, and simplicity. In Against Interpretation (1966), Susan Sontag celebrates what she calls a "new sensibility" (Sontag, 1966, p. 296). A sensibility has been set against the canonization of the high culture of the modern capitalist world. This claim underscores that 'the distinction between 'high' and 'low' culture seems less and less meaningful" (Sontag, 1966, p. 302). This populist attack on the elitism of modernism promotes a refusal of what Andreas Huyssen calls "the great divide [a] discourse which insists on the categorical distinction between high art and mass culture" (Huyssen, 1986, p. viii). With this rationale, postmodernism highlights the distinction between high and popular culture that has come to be regarded "as the 'un-hip' assumption of an older generation" (Storey, 2009, p. 184). This pinpoints the new seriousness emerging in pop music itself, most obvious in the work of performers such as Bob Dylan 
and the Beatles; there is a new seriousness in their work that has been taken seriously in an unprecedented manner within the realm of pop music.

The present study seeks to establish the bluesy folk melody as a beautiful structure that can be appreciated for its refinement and postmodernist/ formalist qualities. The study attempts to rebut the prevailing assumption that excludes popular music from the status of art since some works of popular music are worthy of great admiration on aesthetic grounds, highlighting the research questions below:

- Can popular music be considered art and its products regarded as artworks?

- Does popular music have any sort of positive aesthetic value for society?

- Why are some songs hits?

- Can the bohemian folk singer Bob Dylan be considered a poet?

According to Michael Gray, American folk music, as "music created by the people and for the people", can be divided into four main types: Yankee, Southern poor white, Cowboy and Black, and all four of them appear in Dylan's art in very different guises (Gray, 2006, p. 232). In his Bob Dylan in America (2010), Sean Wilentz explores how the ideas of the folk scene in some points overlap with those of the Beat Generation, and how the intermingling of the two helped shape one of the best songwriters of all times. Wilentz believes that Dylan's first albums were written and composed under the influence of left-wing radical composers, a large musical scene that evolved in the Thirties. The most important folk musician that inspired Dylan was Woody Guthrie, and to a lesser degree Pete Seeger (Wilentz, 2010, p. 27). The artists, in addition to collecting and transcribing popular songs that were in danger of disappearing, used folk music as a tool for radical politics, promoting union organizing and racial justice (Wilentz, 2010, pp. 289). One example would be the folk band the Almanac Singers formed in the late Thirties by Pete Seeger and Woody Guthrie, which in the late Forties evolved into The Weavers. Wilentz states that this band would later prove essential in introducing a younger generation, including Dylan, to especially Guthrie's music, and would help shape the folk revival of the following two decades (Wilentz, 2010, pp. 28-9). Dylan's infatuation with Woody Guthrie is explored in Dylan's Chronicles: Dylan came to New York to find Woody Guthrie, whose songs "ruled [his] universe" (Dylan, 2004, p. 49). He considered Guthrie "the true voice of the American spirit" (Dylan, 2004, p. 99).

Dylan began singing other people's songs in the bars of the Village. His talent came to the attention of producer John Hammond, who invited Dylan to sign a contract with Columbia Records and record his first album. This first album, entitled Bob Dylan (1962), consisted of well-known folk, blues, and gospel songs, and only two original compositions ("Talkin' New York" and "Song to Woody"). The album made little impact and had poor sales. Nevertheless, by the time Dylan released his second album the following year, The Freewheelin', Dylan began to make a name for himself as a singer/songwriter. When The Times They Are A-Changin' came out, his songs were being called protest songs, and Dylan was already being considered a poet-prophet and the spokesman of a generation. $\mathrm{He}$ was a supporter of the Civil Rights Movement and he sang at the March on Washington in 1963 along with his singing partner Joan Baez.

Bob Dylan is the only singer/songwriter to have been nominated for the Nobel Prize in Literature from 1996 onwards, and received the Pulitzer Prize Arts Award in 2008. In 2011, on the occasion of his 70th birthday, the English Department at the University of Bristol organized an academic conference entitled The Seven Ages of Dylan, where the UK's best Dylan scholars celebrated and discussed his career. Most recently, Dylan was awarded the 2016 Nobel Prize in Literature for what the Swedish Academy described as "having created new poetic expressions within the great American song tradition" as stated in the "Banquet Speech" (https://www.nobelprize.org/ nobel_prizes/literature/laureates/2016/dylan-speech_ en.html). The central question tackles Dylan's career: Is Bob Dylan a songwriter or a poet?:

Clouds so swift
Rain won't lift
Gate won't close
Railings froze
Get your mind off wintertime
You ain't' nowhere

_ “You Ain't' Goin' Nowhere” (1967)

Dylan was asked that very question at a press conference in 1965, when he replied, "I think of myself more as a song-and-dance man." The contest intensified in 2004, when rumors spread about Dylan's nomination for a Nobel Prize in Literature, and five books were released almost simultaneously: Dylan's Visions of Sin (2004) by Christopher Ricks, an Oxford 
professor of poetry; Dylan as a Poet's Lyrics: 1962 2001 (2006), a collection of Dylan's songs presented in printed form; Chronicles (2004), the first volume of Dylan's memoir; Bob Dylan Encyclopedia (2006); and Studio A (2005), an anthology about Dylan by such esteemed writers as Allen Ginsberg, Joyce Carol Oates, Rick Moody, and Barry Hannah.

Dylan has been regarded as "Voice of a Generation" with The Freewhelin' Bob Dylan (1963), an album where seven of the thirteen tracks are protest or political songs. He followed this up with The Times They Are A-Changin', which was greeted with accord that in Dylan a poet was found who finally expressed the younger generation's thoughts on political and social injustice, through spectacular imagery. The Times They Are A-Changin' communicates stories as a protest against the world's injustices. The title of the album, The Times They Are A-Changin' depicts social change as being imminent, and the same message is repeated in each stanza of the title song. It is an explicit criticism of authority figures such as politicians, parents, and the cultural elite that makes this protest song so iconic. The lyrics start with "all to gather around" and each stanza except the last one is an address in the imperative: "Come gather, round people", "Come writers and critics", "Come senators, congressmen", "Come mothers and fathers", all of which make the song easy to follow (Ricks, 2004, p. 222). The last verse, "the line it is drawn, the curse it is cast", can be considered a metaphor for something final.

Dylan's work has swerved purposefully into poetry. In 1966, he wrote a book of poems and prose called Tarantula. Many of the liner notes from his 1960s albums were written as epitaphs. For example, "Desolation Row" portrays America as a funhouse and its title alludes to two novels Dylan enjoyed immensely, Steinbeck's Cannery Row (1944) and Kerouac's Desolation Angels (1965) (Polizzotti, 2006, p. 133). Moreover, these lyrics from "Desolation Row" are peppered with literary references:

Praise be to Nero's Neptune

The Titanic sails at dawn

And everybody's shouting

"Which Side Are You On?"

And Ezra Pound and T. S. Eliot

Fighting in the captain's tower

While calypso singers laugh at them

And fishermen hold flowers

— "Desolation Row" (1965)
The criticism of society is present in the ninth stanza, where "Nero's Neptune" subtly symbolizes the emperor of Rome, made infamous by his political murders. The poet uses the brutality of a historical figure to criticize modern society. The sixth stanza begins by presenting another allusion, "Dr. Filth". According to Ricks, "Dr. Filth" is a reference to Marlowe's Doctor Faustus (published in 1604), in which the main character sells his soul to the devil (Ricks, 2004, p. 10). Dr. Filth's nurse is "in charge of the cyanide hole" and has "a card that read have mercy on his soul". A nurse murdering whilst showing mercy is a fraud, which means there are pretenders at Desolation Row, exactly as in the real world. "Desolation Row" is, thus, a figurative description of the world we live in, with its different characters and contemporary issues to be scrutinized and criticized. The insightful poetry is dazzlingly captivating as it paints modern society as a "Desolation Row".

The premise of the current study is the sharp decline of the belief in the superior status of high culture. It is an appraisal of Dylan's artistic career and vocal gestures to examine the way melody in a popular song works in relation to speech and singing, the grand and the ordinary. It historicizes Bob Dylan's protest music of the 1960s within the paradigm of folk music culture. Dylan is the official son of the legacies of social, communal, and ritual music-making that mirrors contemporary pop and rock back to folk and blues, street-sung broadsides, and work songs, the melodies of medieval troubadours and the blessed rhythms of Christianity and Judaism. The study is an attempt to illustrate how musicology and ethnomusicology can contribute to understanding Dylan as a 'performing artist'. The power and originality of Dylan's music constitute a prima facie case that his performances should be considered art and the musician an artist. The attention to popular music offers new perspectives on the philosophy of music and more generally on the philosophy of art.

\section{Historicizing Dylan's Folk Music}

Folk music is historically linked to social and political commentary and its dissenting role increased after it was commonly used to express anti-communist sentiments during the 1950s (Friedman, 2013, p. 102). With the turbulence of the Cold War transitioning into the outbreak of the Vietnam War, the American people began to fear and eventually question the concept of war. Meanwhile, the opposition to the Civil Rights Movement caused even more hardship 
and divisiveness throughout the nation, causing more confusion and rage among the American public (Faber, 1994, p. 50). This period was characterized by a strong folk ideology founded in an idealized Romanticism with a heavy stress on personal expression, and as a counter culture leading to radical activism on race, class, and gender issues and against the war in Vietnam. Folk singers used to recreate tradition in order to speak for other people and report events which had a socio-political significance. The world of the folk musicians was a utopian one, as they believed in a society where people were considered to be completely well whereas the institutions were rotten to the core. It was a period in which radicalism and art went hand in hand. To name a few of them, the artists who were making folk music during this time were Judy Collins, the Kingston Trio, Joan Baez, Bob Dylan, the Limeliters, and the New Christy Minstrels. They were all influenced by Pete Seeger and Woody Guthrie, who belonged to the previous generation of American folk singer/songwriters. What differentiated the youngest group was the desire to be more commercialized. Folk was "revolutionary in its content" (London, 1984, p. 78) and Guthrie was an inspirational, radical figure. What is more, Joan Baez and Bob Dylan merged the music's political history with the more popular rock style during the 1960s, moving folk music into the mainstream (Hall, 2005, p. 122). The shift of Dylan from an acoustic guitar to an electric one made him a revolutionary who mixed "the style of folk protest to the iconoclasm of rock action" (London, 1984, p. 78).

In Acting in Concert: Music, Community and Political Action (1998), Mark Mattern examines music as a form of communicative action in which communities are able to resist, negotiate, and articulate political identities (Mattern, 1998, p. 25). This highlights the notion of 'political music' that is politically committed. 'Political music' has been associated with protest music in America. As such, protest music is politically engaged within resistance movements in the 1960s and the Cold War that followed. Using art as an outlet of self-expression, protest music emerged as a response to the political and social turmoil of the time and the American youth were able to choose what to listen to and were able to give strength and force to a music-driven movement. Music serves as an experiential form of communication. Through art, music relates the experience of the musician to the experiences of the listener, forming a unique bond and creating greater opportunity for "persuasive efficacy". According to Stewart, Smith, and Denton, protest songs serve six major persuasive functions: 1) informing audiences about the past, present, and future of social problems, 2) establishing or defending the self-identity or self-worth of those associated with the cause, 3 ) establishing legitimacy of the movement, 4) prescribing solutions and/or making demands regarding the social problem, 5) promoting cohesion and camaraderie among those involved in the movement, and 6) urging specific actions such as picketing, voting, or removal of troops (Stewart, Smith \& Denton, 2001, p. 137).

A protest song is a song that identifies a social problem and/or calls for action in response to a social or political problem. Protest songs bore a "rhetorical persuasion" sensibility as they "expressed dissent, appealed for changes, attracted support for the movement and influenced attitudes" (Kizer, 1983, p.4). This new popularization has been known as "deliberative Political action" (Matula, 2007, p. 21). Dylan wrote his own protest songs in response to the Civil Rights Movement raging at the time. He gained publicity and stardom in his own career. When describing his style, Dylan explained "I don't think when I write. I just react and put it down on paper ... what comes out in my music is a call to action" (italics mine, Blanton, 2001, p. 6). Thus, Dylan's music became important and impactful to the protest movements of the 1960s, since it inspired the listeners to take an action to change America into a better state. Dylan gained influence in that tumultuous time through his appeal to traditional American values and to the notion of the "common man" - the equality among all American citizens, and that one's merit should be based on virtues rather than status and ethnicity (Dunlap, 2006, p. 549).

The 1963 song "Blowin' in the Wind" communicates a critique of social and political injustice in the form of a series of insightful allegorical questions. Dylan expresses the aspiration of the people for peace: "How many seas must the white dove sail, before she sleeps in the sand?"- the dove being a symbol of peace - and in "How many times must the cannonballs fly, before they are forever banned?" He also highlights freedom and equality in: "How many years can some people exist, before they're allowed to be free?" He refers to the predicament of black Americans, who were still very much second-class citizens in the 1960s.

The image of freedom is manifested in an excerpt from "Subterranean Homesick Blues", which 
compares America to an authoritarian and rigid police state:

Look out, kid, it's something you did, God knows when, but you're doing it again, You better duck down the alleyway, lookin' for a new friend,

The man in the coonskin cap, in the big pen, Wants eleven dollar bills, but you only got ten

\section{_ “Subterranean Homesick Blues" (1965)}

The depicted person is chased by teachers, policemen, tax collectors, and the army for committing no crime other than being subject to their prejudice. In the face of such a repressive government, Dylan offers advice to the Americans: "You don't need a weatherman to know which way the wind blows." The lack of opportunity in America is summed up perfectly in the delightfully negative and cynical line "Twenty years of schoolin' and they put you on the day shift."

The lyrics of The Times They Are A-Changin' display a potent metaphor for change, the rising tide of powerful waters: "and admit that the waters around you have grown", reproaching people so as to wake them up and urge them to recognize the dystopia before it is too late (Manzella, 2012, p. 31). The metaphor stands for the pivotal events in America in the 1960s, especially the Civil Rights Movement. One major event was the March on Washington, where Martin Luther King Jr. held the famous "I have a Dream" speech, and where Dylan also got to play live. The following line, "And accept it that soon or you'll be drenched to the bone", continues the metaphor's motif of a rising flood that signifies an escalating injustice that will soon be unbearable. In addition, the line: if one does not "swim", one will "sink like a stone" hammers home the seriousness of the issue. The second stanza acts as a metonymy since the speaker refers to "writers and critics" to set a critique against those who "prophesize with [their] pen". It can be interpreted as condemnation of other musicians, or publishers of the key newspapers. The "senators, and congressmen" in the third stanza is also a metonymy for the rulers, since both "senators and congressmen" are closely associated with Congress, which in turn is commonly used as a metonymy for the American government (Littlemore, 2015, p. 102).

Dylan has exhibited a critical attitude to the idea of material gains. Dylan's evaluation of the American Dream can be seen in these quotes: "There's no success like failure, and failure's no success at all," "Up on housing project hill it's either fortune or fame, you must pick one or the other though neither of them are to be what they claim," "You find out when you reach the top, you're on the bottom," and in the expression "Money doesn't talk, it swears." "A Hard Rain's A-Gonna Fall" is a song which fully expresses the pitfalls of the American Dream. Dylan completely exposes the dark side of the lofty American Dream. America-being associated with the "Hard Rain"is a desolate and barren place filled with "crooked highways", "sad forests", and "dead oceans". The horrible imagery is that "I saw a new born baby with wild wolves all around it." It is America that is morally dead: "I saw guns and sharp swords in the hands of young children", "where the hunger is ugly, where the souls are forgotten". It is an America with modest prospects for material gain: "I saw a highway of diamonds with nobody on it", "I saw a white ladder all covered with water". This line subtly refers to the vague nature of Benjamin Franklin's idea of the ladder of success, which vibrates the notion of 'from rags to riches' as an integral characteristic of the American Dream.

Finally, Dylan has established "himself as an acoustic singer/songwriter in New York City's urban folk scene" (Larry \& Waterman, 2003, p. 70), a genre of popular music in the early 1950s. In Song and Dance Man: The Art of Bob Dylan (1981), Michael Gray ponders that "before [Dylan] you could say that pop was like football. Millions of people liked it millions of people like fish and chips - but it didn't matter. Dylan made it matter" (Gray, 1981, p. 115). As a songwriter/composer, Dylan has distinguished himself from his contemporaries such as Joan Baez, Judy Collins, Tom Paxton, and Phil Ochs by his outstanding gift for "poetic imagery and metaphor and a searing intensity of feeling, sometimes moderated by a quirky sense of irony, and for his rough-hewn performance style, combining aggressive vocal, guitar, and harmonica and demonstrating affinities to rural models in blues and earlier country music" (Larry \& Waterman, 2003, p. 11). Dylan's career in 1965 was crucial with the release of his fifth album, Bringing It All Back Home, setting his epochal influence on American popular music. The album features intense and unfamiliar poetic imagery embraced in the realm of surrealist melodious lyrics as exemplified in "Mr. Tambourine Man", the first milestone folk-rock hit. Dylan is a postmodernist since he borrows from diverse musical traditions contributing to humanity's stylistic language, as well as politics of resistance, 
opposition, and freedom.

\section{DYLAN: A POSTMODERN 'SINGERSONGWRITER'}

The problematic configuration of the "poetry of pop" has been pinned down (Frith, 1996, p. 176) to allude to Dylan's "heroic merging of words, music and performance as 'song-poet"' (Day, 1988, p. 5) regarded as "a multi-dimensional art" (Day, 1988, p. 5 ). The borderline between pop songs and poetry has been blurred since the Beatles, for instance, printed the lyrics with the record "and some song writers have had their words printed as books: Dylan, Shane MacGowan, [and] John Mitchell" (Moore, Allan, 2003, p. 42).

In Bob Dylan (2010), Greil Marcus refers to Dylan's sophisticated artistic significance as a folk composer and a national savior to his American fans. Dylan first emerged as a folk music singer/songwriter in the 1960s New York music scene, and very quickly became a prominent and influential figure in American popular music. Many of his early songs focused on political issues. When he moved away from such themes, he was met with a great deal of resistance from his devoted followers. Members of the folk community regarded his arrival on the folk music scene as if it had been anticipated, even divinely ordained, and the audience opportunistically anointed him as a savior. Furthermore, they expected this manufactured messiah to give them direction, to become a symbol of their cause. Yet, he never detached himself from his ties to the folk community and instead, Dylan has situated himself in "a space between his position as leader of a movement and exiled ex-communicant" (Marcus, 2010, pp. 319-20).

"What did I owe the rest of the world? Nothing," Dylan asks (Dylan, 2004, p. 123), but at the same time he sings and entertains as a "song and dance man". This negotiation of his place in society is a crucial part of his shifting and contested identities, and in some ways, such contestation has contributed to the shift of his musical style in the mid-1960s from urban folk to electrified rock music. This squabble, for that matter, between Dylan and the audience, is now discussed as one of the landmark moments in the history of American Popular Music (Larry \& Waterman, 2010, p. 284) providing a key insight into the ways in which musical identities are constructed and developed among musicians and their listeners. As a constant factor within these constructed identities, Dylan is not only a musician who plays his instrument and sings, but also an artist who presents and shares his intellect and values with society. Though Dylan kept releasing new records during the " 80 s and early ' 90 s - the time periods that some fans call the "born-again period" because of his reverential use of Christianity in his lyrics - he was trying to "find Jesus", in whom Dylan was once metaphorically thought to be, presumably, seeking direction in his life.

The shift from folk to rock, from the acoustic to the electric guitar, and from old folk ballads to Beat-inspired verbal wit upset Dylan's fans, who considered it a sell-out and a betrayal of the folk revival's values. This became popularly known as the electric controversy. Dylan released Highway 61 Revisited, which featured "Like a Rolling Stone". The song has become a revolutionary track and one of the most influential compositions in post-war popular music, and helped Dylan become a rock icon. In 1966, he issued Blonde on Blonde, his first double album. The choice to introduce electric instrumentation demonstrates Dylan's interest in experimentation: "By continuing to use folk sources, here, especially, blues, but transformed into rock and roll, Dylan did not invent a new genre, 'folk rock' a term which he always rejected, but rather a distinctive sound that was at that moment his alone (Shumway, 2009, p. 115). Dylan called himself "a trapeze artist" (Ephron \& Edminston, 1970, p. 65), to stress the fact that he liked very much to experiment with music, considering himself neither a poet nor an icon, as the press and the public seemed to depict him. Dylan's lyrics are surely innovative in the sense that he gave "seriousness" (Shumway, 2009, p. 117) to popular songs, since before him they were concentrated on the music and not on the sense or content of the lyrics. In fact, speaking about folk songs, Dylan argues that "folk music is the only music where it isn't simple ... It's never been simple ... It's weird, full of legend, myth, Bible and ghosts" (Ephron \& Edminston, 1970, p. 66).

Under the "Books" section of his official website, one can find a collection of published works on Dylan, books written by Dylan like the Chronicles and the novel Tarantula, as well as what could be considered Dylan's favorites like Guthrie's Bound for Glory, Rimbaud's A Season in Hell, Kerouac's On the Road, and Ginsberg's Howl and Kaddish. When it comes to Kerouac's novels, references can be found in the titles of Dylan's songs from the electric trilogy: On the Road becomes "On the Road Again", The Subterraneans is turned into "Subterranean Homesick Blues", Visions of Gerard is reflected in "Visions of 
Johanna", and "Desolation Row" is a reference to Desolation Angels. The influence of Allen Ginsberg, on the other hand, is even more prominent: "Dylan's debt to Howl (and the later Kaddish) and by the time Dylan became a celebrity, his friendship with Ginsberg was a public fact" (Gray, 2006, p. 255).

Followers and the media have referred to his lyrics as poetry, and perceived him more as a poet than a singer/songwriter. The immediate connection to poetry is visible in Dylan's pseudonym and its direct reference to Dylan Thomas. However, in his Chronicles, the songwriter explains that the choice of changing his name from Robert Zimmerman to Bob Dylan was rather based on the sound than on a strong and important reference to the Welsh poet. Dylan's first choice had been Robert Allyn, but he changed his mind after reading some poems by Thomas: "Dylan and Allyn sounded similar ... I couldn't decide - the letter D came on stronger ... Bob Dylan looked and sounded better than Bob Allyn" (Dylan, 2004, pp. 78-9). Dylan describes how he read all kinds of books about philosophy, fiction: "I read the poetry books, mostly Byron and Shelley and Longfellow and Poe. ... I read a lot of the pages aloud and liked the sound of the words, the language" (Dylan, 2004, pp. 37-8). In New York, Dylan became even more interested in poetry: "I had broken myself of the habit of thinking in short song cycles and began reading longer and longer poems to see if I could remember anything I read about in the beginning. I trained my mind to do this, had cast off gloomy habits and learned to settle myself down ... I began cramming my brain with all kinds of deep poems" (Dylan, 2004, p. 56).

"When The Ship Comes In" in The Times They Are A-Changin' exhibits figurative language that makes it both vivid and intricate. The first part of the song states that good things will happen "the hour when the ship comes in", but we are not at first certain who comes with the ship, or what intentions it might have. The very beginning of the song portrays the stillness "when the winds will stop", and when "the breeze will cease to be breathin" "as examples of personifications. However, the continuation "like the stillness in the wind, before the hurricane begins", a playful adaptation of the old saying "the calm before the storm", shows that a change is about to come. The second stanza is tied together with the first and it keeps hinting that "the ship" comes with good intentions regarding this change: "and the wind will pound, and the morning will be breaking", are further personifications indicating that all things existing will react to "the ship" as it comes. The change about to happen will not escape anyone. The poetry in the song is challenging since the poet presents a mixture of personifications and metaphors, sometimes followed by the phrase "the hour that the ship comes in". Most of the figurative language is allusive rather than clearcut as in "Fishes will laugh as they swim out of the path" and the "raging wind" implies that the change is forceful and potentially destructive, the "laughing fish" becomes a metaphor for the positive result. The fourth stanza makes a slightly clearer connection to the Civil Rights Movement by mixing its metaphors, with the implication that the ship represents social change:

And the words that are used

For to get the ship confused

Will not be understood as they're spoken

_ “The Times They Are A-Changin"” (1964)

The fight for civil rights was a long and arduous process, and the opposing voices were loud, yet the "ship" has caught up such speed that it is impossible to stop. The lyrics also communicate that the ship "drifts on to the shoreline" and that "the sun will respect every face on the deck", where "the sun" is used as a signifier of acceptance: the sun is allseeing, and respects every single person regardless of the color of their skin. In addition, the stanza that follows brings up "the ship's wise men", who "will remind you once again that the whole wide world is watching". The "wise men" is a metonymy for the leaders in the Civil Rights Movement, people like Martin Luther King Jr. His "I have a Dream" speech from 1963 was a reminder of what kind of place Earth could, and should be. Similarly, the protest chant "the entire world is watching!" was a call for America to become more humane.

Todd Kennedy argues that Dylan desires his lyrics to be heard, not read; they are songs, not poems. Nevertheless, Kennedy still believes that Dylan's lyrics can be discussed in terms of their relation to modern poetry and he sees the singer's artistic production as having a rhizomatic form emerging "as neither pure music nor pure poetry, but rather both at the same time" (Kennedy, 2009, p. 41). Moreover, Kennedy explains that "the rhizome, as an aesthetic and linguistic structure, establishes connections between semiotic chains, organizations of power, and circumstances relative to the arts, sciences and social struggles"; therefore, the rhizome becomes 
essential in inserting Dylan into the tradition of performance literature, an artistic form that dates back to the troubadours, only with the technological ability to record the oral performance in an audio format (Kennedy, 2009, p. 41). By rhizomatic, Kennedy refers to the philosophical concept developed by Gilles Deleuze and Felix Guattari where the rhizome stands for a horizontal and non-hierarchical conception of thinking, as opposed to a vertical hierarchy dualism of thinking (Deleuze \& Guattari, 1972, p. 80).

Christophe Lebold notes that a major part of Dylan's success is due to the fact that the listeners of his songs experience a specific literary pleasure that arises from the concurrence of three literary activities: (1) Dylan's lyrics are first written, and then performed; (2) the lyrics are rhythmically re-written by the voice; and (3) the songs are used by Dylan to write himselfin other words, to create a series of numerous personae, or numerous "Bob Dylans" (Lebold, 2007, p. 57). Lebold refers to Roland Barthes's analysis of literary pleasure in The Pleasure of the Text (1973), and more specifically to the critic's distinction between readerly and writerly texts. According to Lebold, Dylan's songs would fall under writerly texts, since their semantic openness and sophisticated imagery require a greater hermeneutic activity from the listener/reader (Lebold, 2007, p. 60). Lebold acknowledges that Dylan's lyrics are "inherently poetic"; however, he believes that in Dylan's case "the poet is also a performer and much of poetry lies in the performance and music" (Lebold, 2007, p. 59).

Stephen Scobie sets a connection between Dylan's use of black glasses and the way players in Greek theatre used masks "to conceal identity and to express character" (Scobie, 2003, p. 46). The dramatic function of the mask is to assume many roles, so too Dylan's postmodernist minimal performance "multiplies identity" and allows "identity itself to become an artistic construct" (Scobie, 2003, p. 47) or a persona adopting a voice of the role of a fictional character" (Scobie, 2003, p. 48). For Scobie, Dylan's creativity resides in his idiosyncratic performing identity - that is, the appearance and manner of the singer undergoes many changes over time. Scobie highlights the notion of "the mask of originality" (Scobie, 2003, p. 48) to explain how Dylan has played different personas such as the "protest singer, rock star and country gentleman" (Scobie, 2003, p. 48). This underlines the "carnivalesque" rites that urge Dylan to change his identity to foreground a new persona on the stage.
Dylan's musicianship foregrounds the term 'soundscape' or 'acoustic ecology' that was introduced by R. Murray Schafer to indicate how the sonic environment influences our perception and knowledge and to approach "the world soundscape as a macrocosmic musical composition" (Schafer, 1973, p. 29). He coined the term 'soundmark' (from landmark) to emphasize how "keynote sounds of a landscape" can imprint "themselves so deeply on people hearing them" (Schafer, 1994, p. 10). Dylan has manifested an awareness of the sound and the texture of his surroundings. In this respect, Robert Shelton writes: "He was so aware of his surroundings, in every situation, it was almost like he couldn't write fast enough ... Dylan would get thoughts and reactions and he would stop on a street corner and write things down" (Shelton, 1986, p. 136). Dylan himself has recalled how when he first came to New York City, he found the sound of trains comforting:

I'd seen and heard trains from my earliest childhood days and the sight and sound of them always made me feel secure ... The big boxcars, the iron ore cars, freight cars, passenger trains, Pullman cars. There was no place you could go in my hometown without at least some part of the day having to stop at intersections and wait for the long trains to pass.... The sound of trains off in the distance more or less made me feel at home, like nothing was missing.... The ringing of bells made me feel at home, too (Dylan, 2004, p. 31).

Within the realm of the 'sonic environment', Schafer explains how trains have communicated a set of "rhythms, pitches and timbres into human life; the chuffing engine, the escaping steam, the rattling of coaches, the clatter of tracks, the squeaking of wheels" (Schafer, 1994, p. 81). Dylan's consciousness of the sonic textures of the environment has been his attempt to utilize the texture of his surroundings and its sounds create a natural music played in a semidreamlike state.

\section{DYLANESQUE: POETICS OF RHYME AND MUSIC}

Dylan's American popular music reflects "a kaleidoscope of contributions, a cross-fertilization of styles, and a blending of dreams to convey a ferment artistic drive" (italics mine, Larry \& Waterma, 2003, p. 3 ). Bob Dylan's music is full of riffs, blues sequences, shout and fall patterns, pentatonic melodies, minor thirds, and chants - all heavily related to blues, 
folk, gospel, and country music. It is the music that takes the pleasures of repetition, of circularity, of the recurring familiar tune, of apparent stasis, and integrates them with Dylanesque poetics of rhyme and music, delivered with his idiosyncratic and intense range of voices. Richard Middleton defines riff as "short rhythmic, melodic, or harmonic figures repeated to form a structural framework" (Middleton, 1990, p. 125).

Paul Williams refers to Dylan's music in which melodies are integrally tied up with rhythms of his vocal delivery and with the rhythms of instrument. He observes that "a primary aspect of [Dylan's] songwriting and performance is a kind of percussive lyricism, as if every word were a pulse in a rhythmic flow" (Williams, 1990, p. 69).Williams emphasizes Dylan's significance as a performing musician; the way he has continuously re-arranged songs in concert. This supports the claim that Dylan's most forceful renditions of songs have been in live performances, rather than recorded in the studio. To capture a fresh performance, the stage is where Dylan's songs are most alive and it is also a challenge to the frozen studio record.

What is remarkable is Richard Middleton's notion of the "magical musicalization of the everyday" (Middleton, 1990, p. 229). He underscores the power of popular songs with ordinary words that might seem commonplace to possess the "affective force and kinetic grace" (Middleton, 1990, p. 229). This is the story with Dylan, whose songs can be midst the daily routine breathed alive. Dylan's riff is a simple musical device - a short rhythmic melodic phrase often repeated continuously for the duration of a song. Williams emphasizes the riff as the key to how Dylan's music works, particularly in concerts. Williams writes: "when the band is directed to vamp on the riff for long non-vocal passages, the riff itself starts speaking to the song's listeners as though these were whole new verses of evocative, mind-blowing, Bob-Dylanin-his-prime lyrics" (Williams, 2004, p. xiii). The riff allows the song to have a form, to take a shape. The cyclical repetition of musical phrases was more pronounced and emphasized in live performances. Recurring strophic patterns or loops, and repetition are very important in popular songs. The musician or songwriter draws the listener in by introducing subtle changes of tempo, or texture or by playing with the dynamics of the song. Dylan's use of a repeating, cyclical pattern builds intensity through the music. Dylan's words often work as sounds, used for their phonetic, rhythmic and evocative character rather than their semantic or representational qualities; for the sonorous quality of the rhymes within the music, as Dylan commented: "The semantic meaning is all in the sounds of the words" (Dylan, 2004, p. 173-4).

Dylan's music and songs convey meaning through the melodic contour of the song, in particular through the use of rising and falling pitch. Peter Van Der Merwe shows the relation between blues and rock music within the notion of the 'holler', the 'shout and fall', or the 'tumbling strain'. He speculates that the holler is "probably as old as song itself: a series of improvised, constantly varied strains, all descending to the same low point and often to the same figure". He calls it "the true 'endless melody', without any further organizing principle beyond the grouping of the strains into irregular waves, which themselves taper from high to low" (Van Der Merwe, 2004, p. 444). A dramatic rise in pitch followed by a quick drop characterizes songs that entail a tense 'affective outpouring', a musical gesture characterized as "selfoffering of the body" and then a more relaxed, inward looking descent (Middleton, 1990, p. 207). A sudden rising and falling pattern is a key feature of Dylan's songs. It is one of the ways to convey emotion and to add dynamism and drama to the narrative. Dylan's vocal performance manifests his skill as a singer in shifting between pitches and singing with an irregular meter.

Finally, Dylan has always been chiefly "a performing artist" advocating a rhythmic guitar in his bohemian folksy style and the nasal folk-blues voice. He has not composed his songs to be recorded: "a record is not that monumental for me to make ... it's just a record of songs" (quoted in Rosenbaum, 1978, p. 70). In this sense, Paul Williams argues that Dylan's "finest work has been done outside of the confines of the recording studio" (Williams, 1992, p. xiv). Therefore, most of Dylan's recordings can be considered, for example, to be a document of his political songs manifesting the spirit of the age in terms of protest and resistance. Performance has been intermingled with non-verbal signs like music, voice, and the personae of the performer, the latter being "the fictional or semi-fictional identities that the artist constructs in the lyrics and his public appearances" (Lebold, 2001, p. 9), putting in consideration the aesthetics of folk music traditions that are as complex and sophisticated as canonical high culture. 


\section{CONCLUSION}

Postmodernism has manifested itself on the changing nature and understanding of music and its forms. It challenges the $19^{\text {th }}$ century doctrine of 'Art for Art's Sake', a universal aesthetic of music that transcends social and cultural context, to give the popular music its due and rightful position as a serious form of art within the paradigm of resistance and political protest. Music has become closer to the public and has been presented in the form of show or performance, event and happening rather than literature for personal and intimate reading. Postmodernism also, in its formal freedom and its experimentation, achieves innovations of its own, as seen in Dylan's songs which underscore irregular and open, often fragmented forms, as well as the rhythms of popular music such as blues and rock. Popular music, from folk to rock, has contributed to a shift in the perception of what poetry was, detecting thus poets among musicians, with Dylan as the first and clearest example. Today's criticism tends to look at songs as a complex artifact made of lyrics, sound, voice, and the persona of the musician performing his or her work. The recognition of this complexity has brought on the awareness that non-verbal elements can also contribute to the interpretation of lyrics, just like the changes in musical influences and in the image of the performer. This is especially important for Dylan, an artist who has based his career on constant shifts in poetic influences and musical genres, and on the transformations of his public image. What is unique about Dylan's postmodern style is its hybridity and intertextuality, by its license to (re)create images from the past while locating the residue of previously authored texts within the "original". Dylan's vision of rock music and folk literacy effectively laid the design for the soundtrack to the whole counter-cultural experiment. His electric phase marked symbolic lyrics and Dylan switched a simple jeans-and-shirt outfit for a leather jacket and a pair of hip sunglasses. When it comes to musical albums, besides the audio recording, they contain pictures, images and, in Dylan's case, poems printed on the covers, which along with the lyrics form the whole of the album. This is concrete proof that postmodernism is always in a state of $f l u x$ to feature performance details as vocal gestures, instrumental styles, visual identities.

\section{ENDNOTE}

1) Bob Dylan (2016). "Banquet Speech". https://www. nobelprize.org/nobel_prizes/literature/laureates/2016/ dylan-speech.html \& Dylan's Nobel lecture @ http://www. svenskaakademien.se/en/nobel-lecture

\section{REFERENCES}

Bennett, Tony, Mercer, Colin \& Woollacott, Janet (eds). (1986). Popular Culture and Social Relations. Milton Keynes: Open University Press.

Bennett, T. (1980). Popular Culture: A Teaching Object. Screen Education, 34, pp. 17-29

Day, A0. (1988). Jokerman, Reading the Lyrics of Bob Dylan. Oxford: Blackwell.

Deleuz, G. \& Guattari, F. (1972). Anti-Oedipus: Capitalism and Schizophrenia. Minnesota: University of Minnesota Press.

Dunlap, J. (2006). Through the Eyes of Tom Joad: Patterns of American Idealism, Bob Dylan, and the Folk Protest Movement. Popular Music and Society, 29(5), pp. 549-573.

Dylan, Bob (2004). Chronicles, Volume One. New York: Simon and Schuster.

Dylan, Bob (2016). Banquet Speech. https://www. nobelprize.org/nobel_prizes/literature/ laureates/2016/dylan-speech. html.

Ephron, N. \& Edminston, S. (1970). Bob Dylan Interview. The Age of Rock 2: Sights and Sounds of the American Cultural Revolution, edited by Jonathan Eisen, pp. 63-71. New York: Vintage.

Eyerman, R. \& Jamison, A. (1995). Social Movements and Cultural Transformation: Popular Music in the 1960s. Media, Culture \& Society, SAGE 17, pp. 449-468.

Farber, D. (1994). The Age of Great Dreams: America in the 1960s. London: Macmillan.

Friedman, J. (2013). History of Social Protest in Popular Music. London: Routledge.

Frith, S. (1996). Performing Rites, On the Value of Popular Music. Oxford: Oxford University Press.

Gray, M. (1981). Song and Dance Man: The Art of Bob Dylan. London: Hamlyn.

Gray, M. (2006). The Bob Dylan Encyclopedia. London, UK: Continuum.

Gray, R. (1990). American Poetry of the Twentieth Century. London-New York: Longman.

Grossberg, L., Frith, S., \& Goodwin, A. (eds). (1993). Sound and Vision: The Music Video Reader. New York \& London: Routledge.

Hall, M. (2005). Crossroads: American Popular Culture and the Vietnam Generation. Lanham: Rowman and Littlefield Publishers.

Huyssen, Andreas. (1986). After the Great Divide: 
Modernism, Mass Culture, and Postmodernism. London: Macmillan.

Kennedy, T. (2009). Bob Dylan's Highway Shoes: The Hobo-Hero's Road Through Modernity. Intertexts, Vol. 12, 1/2, pp. 37-58.

Kizer, E. J. (1983). Protest Song Lyrics as Rhetoric. Popular Music \& and Society, Vol. 9(1), pp. 3-11.

Larry, S. \& Waterman, C. (2003). American Popular Music. Oxford: Oxford University Press.

Larry, S. \& Waterman, C. (2010). American Popular Music: From Minstrelsy to MP3. New York: Oxford University Press.

Littlermore, J. (2015). Metonymy: Hidden Shortcuts in Language, Thought, and Communication. Cambridge: Cambridge University Press.

Lebold, C. (2007). A Face Like a Mask and a Voice that Croaks: An Integrated Poetics of Bob Dylan's Voice, Personae, and Lyrics. Oral Tradition, Vol. 22, No. 1, pp. 57-70.

London, Herbert I. (1984). Closing The Circle: A Cultural History of the Rock Revolution. Chicago: Nelson - Hall.

Manzella, T. (2012). How to Analyze the Music of Bob Dylan. USA: Abdo Consulting Group.

Marcus, G. (2010). Bob Dylan: Writings 1968-2010. New York: Public Affairs

Marshall, L. (2007). Bob Dylan: The Never Ending Star. Cambridge: Polity Press.

Matula, T. (2007). Pow! to the People: The Make-Up's Reorganization of Punk Rhetoric. Popular Music and Society, 30(1), pp. 19-38.

Mattern, M. (1998). Acting in Concert: Music, Community, and Political Action. New Brunswick, New Jersey: Rutgers University Press.

Middleton, R. (1990). Studying Popular Music. Philadelphia: Open University Press.

Moore, A. (2003). Analyzing Popular Music. Cambridge: Cambridge University Press.

Murray, A. (1976). Stomping the Blues. New York: Da Capo Press.

Negus, K. (2008). Bob Dylan: Icons of Pop Music. University of California: Indiana University Press.

Polizzotti, M. (2006). Bob Dylan's Highway 61 Revisited. New York \& London: Continuum.

Ricks, C. (2004). Dylan's Visions of Sin. Viking: London.

Rosenbaum, R. (1978). Playboy Interview: Bob Dylan, a Candid Conversation with the Visionary Whose Songs Changed the Times. Playboy, pp. 61-90.

Schafer, M. (1973). The Music of the Environment. Audio culture: Reading in Modern Music, Christoph Cox and Daniel Warner (eds.). New York \& London: Continuum, 2005, pp. 29-39.
Schafer, Murray. (1994). The Soundscape: Our Sonic Environment and the Tuning of the World. Rochester Vermont: Destiny Books.

Scobie, S. (2003). Alias Bob Dylan Revisited. Calgary: Red Deer Press.

Sontag, S. (1966). Against Interpretation. New York, Deli: PICADOR.

Shelton, R. (1986). No Direction Home: The Life and Music of Bob Dylan. New York: Da Capo Press.

Shumway, David R. (2009). Bob Dylan as a cultural Icon. In The Cambridge Companion to Bob Dylan, edited by Kevin J. H. Dettmar, pp. 110-121. Cambridge: Cambridge University Press.

Steward, S. \& Denton, Jr. (1984). Persuasion and Social Movements. Prospect Heights, IL: Waveland Press.

Storey, J. (2009). Cultural Theory and Popular Culture: An Introduction. London/New York: Pearson Longman.

Tagg, P. (1994). Subjectivity and Soundscape, Motorbikes and Music, in H. Järviluoma (ed) Soundscapes: Essays on Vroom and Moo. Finland: University of Tampere Press.

Turner, G. (1996). British Cultural Studies. London: Routledge.

Van Der Merwe, P. (1989). The Origins of the Popular Style. Oxford: Oxford University Press.

Van Der Merwe, P. (2004). Roots of the Classical, The Popular Origins of Western Music. Oxford: Oxford University Press.

Wilentz, S. (2010). Bob Dylan in America. New YorkToronto: Doubleday.

Williams, R. (1983). Keywords. London: Fontana.

Williams, P. (1990). Bob Dylan, Performing Artist 1960 1973. Xanadu: London.

Williams, P. (1992). Bob Dylan, Performing Artist 1974 1986: The Middle Years. New York: Omnibus Press.

Williams, P. (2004). Bob Dylan, Performing Artist, 1986 1990 and Beyond: Mind Out of Time. New York: Omnibus Press.

\section{Discography}

Dylan, Bob (1963). The Freewheelin' (Music CD). Columbia Records, New York.

Dylan, Bob (1964). The Times They Are A-Changin' (Music CD). Columbia Records, New York.

Dylan, Bob (1965). Bringing It All Back Home (Music CD). Columbia Records, New York.

Dylan, Bob (1965). Highway 61 Revisited (Music CD). Columbia Records, New York. 